\title{
Laboratory Features of Home Health Care Patients
}

\author{
Evde Bakım Hastalarının Laboratuvar Özellikleri
}

\section{Zeynep Karaali', Beste Tacal Aslan² ${ }^{2}$ Mehmet Burak Aktuğlu', Macit Koldaş ${ }^{3}$ Elif Sinem İplik ${ }^{4}$, Bedia Çakmakoğlu ${ }^{5}$}

\author{
'Department of Internal Medicine, Haseki Training and Research Hospital, İstanbul, Turkey \\ 2Department of Basic Medical Sciences, Medical Biology and Genetics, School of Dentistry, University of Marmara, Istanbul,Turkey \\ 3Department of Clinical Biochemistry, Haseki Training and Research Hospital Istanbul, Turkey \\ ${ }^{4}$ Department of Pharmaceutical Microbiology, School of Pharmacy, İstanbul Yeni Yüzyil University, İstanbul, Turkey \\ ${ }_{5}^{5}$ Department of Molecular Medicine, Aziz Sancar Institute of Experimental Medicine, İstanbul University, İstanbul, Turkey
}

Cite this article as: Karaali Z, Tacal Aslan B, Aktuğlu MB, Koldaş M, Iplik ES, Çakmakoğlu B. Laboratory Features of Home Health Care Patients. Experimed 2019; 9(1): 16-22.

\begin{abstract}
Objective: The increasing need for home health care services is essential for the elderly population and also for people with disabilities, chronic illness, or terminal-phase disease in Turkey and around the world. The aim of this study was to statistically analyze the laboratory data of patients who were followed up by the Home Health Care Units of Haseki Training and Research Hospital.
\end{abstract}

Materials and Methods: The study population included 575 patients who registered for home health care services at Istanbul Haseki Training and Research Hospital between 2011 and 2013. The patients' database records were analyzed according to sex, age group, types of disease, and laboratory findings.

Results: Our results are consistent with the literature in that the patients aged 65 years or over and being followed up by a home care unit had high C-reactive protein but low albumin levels, and the prevalence of anemia was common among these patients $(p<0.05)$.

Conclusion: The results of the study can be used to support the introduction by health policy makers and health professionals of home care as an alternative delivery system in the Turkish health sector.

Keywords: Home health care, age, geriatrics, disease

\section{INTRODUCTION}

The rising proportion of older people is one of the main reasons for the need of home care services but the increasing rate of disabilities and chronic illnesses has also increased the demand for home health care in all societies across the world (1).

Home health care is a formal, regulated, program of care that includes a number of therapeutic services such as nursing care; physical, occupational and speech-language therapy; and medical social services for promoting and restoring

\section{öz}

Amaç: Evde sağlık hizmetleri, yaşlı popülasyonu engelli insanlar, kronik hastalığı olan insanlar terminal dönemdeki hastalardan dolayı Türkiye ve dünyada artış göstermektedir. Bu çalışmanın amacı, Haseki Eğitim ve Araştırma Hastanesi Ev Sağlık Birimleri tarafından takip edilen hastaların laboratuvar verilerini istatistiksel olarak analiz etmektir.

Yöntemler: Çalışmaya, 2011-2013 yılları arasında İstanbul Haseki Eğitim ve Araştırma Hastanesi evde sağlık hizmetinden yararlanan 575 hasta dahil edilmiştir. Hastaların veri tabanı kayıtları cinsiyet, yaş grubu, hastalık tipleri ve laboratuvar bulgularına göre analiz edilmiştir.

Bulgular: Elde ettiğimiz sonuçlara göre, literatürle uyumlu olarak, evde bakım ünitesinde izlenen 65 yaş ve üzeri hastaların yüksek C-reaktif proteinleri, ancak düşük albümin seviyelerine sahip oldukları ve anemi prevalansının bu hastalar arasında yaygın olduğu görülmüştür $(p<0.05)$.

Sonuç: Çalışma sonuçları, sağlık politikalarını düzenleyenler ve sağlık uzmanları tarafından Türk sağlık sektöründe alternatif bir sistem olarak, evde bakım ünitelerinin kullanılabileceğini düşündürmüştür.

Anahtar Kelimeler: Evde sağlık bakım ünitesi, yaş, geriyatri, hastalık

health, while reducing the effects of disability and illness, delivered by a variety of health care professionals in the patient's home when care in the hospital is no longer required $(2,3)$. Treating patients with acute and chronic medical conditions in their homes is an increasingly common model for the delivery of health care in the developed world (4).

Home care services started in developed countries. Since the 1990s, home health care has been one of the fastest developing fields in health care in the United States of America and other Western countries (5). Home care services 
were first defined in Public Health Law No. 1593. They were further elaborated in the Socialization of Medical Services Law, No. 224, on January 5, 1961 (6). In Turkey, large cities such as Istanbul and Ankara are the main locations with home health services (5). Nonetheless, the families of elder people or patients are not adequately informed and hence do not benefit from home care services.

Maternal and child health are fields on which services usually focus. Some basic procedures such as blood pressure measurement, catheter care, administration of injections, medication reminders, oxygen therapy, nutritional evaluation, and other health and lifestyle information, and advice and support are applied during the visit, which are crucial for patients (7-9).

The diseases mostly seen in patients who require home health care include diabetes mellitus; heart disease, including congestive heart failure; malignant neoplasm; chronic obstructive pulmonary diseases; essential hypertension; cerebrovascular disease; ischemic heart disease; cerebrovascular disease; major depressive illness; chronic non-contagious illnesses such as cancer; and contagious diseases such as tuberculosis. People with a physical disability or injury; newborns aged 0 to 1 month who require phototherapy treatment; people with mental disorders; and those with addictions also profit from home care services (10).

Home care services have many advantages such as improving quality of life, providing independence at home, improving recovery desire and morale, and decreasing exhaustion. Accordingly, these services are preferred by individuals and governments because of these advantages and also the potential for cost savings $(11,12)$.

Table 1. Distribution of Diseases According to Etiology

\begin{tabular}{lc}
\hline Sex (\%) (F/M) & $69.4 / 30.6$ \\
\hline Hypertension (\%) (Yes/ No) & $69.6 / 30.4$ \\
\hline Diabetes Mellitus (\%) (Yes/ No) & $69.6 / 30.4$ \\
\hline Heart Failure (\%) (Yes/ No) & $94.4 / 5.6$ \\
\hline Ischemic Heart Disease (\%) (Yes/ No) & $97.7 / 2.3$ \\
\hline Chronic Renal Failure (\%) (Yes/ No) & $99.8 / 0.2$ \\
\hline Alzheimer (\%) (Yes/ No) & $85.4 / 14.6$ \\
\hline Cerebrovascular accident (\%) (Yes/ No) & $66.1 / 33.9$ \\
\hline Epilepsy (\%) (Yes/ No) & $97.2 / 2.8$ \\
\hline Parkinson's Disease (\%) (Yes/ No) & $98.4 / 1.6$ \\
\hline Malignancy (\%) (Yes/ No) & $95 / 5$ \\
\hline Trauma (\%) (Yes/ No) & $96.7 / 3.3$ \\
\hline Other (\%) (Yes/ No) & $90.3 / 9.7$ \\
\hline
\end{tabular}

\section{MATERIALS AND METHODS}

In total, 575 patients who registered for home care between April $1^{\text {st }}, 2011$, and December $31^{\text {st }}, 2013$, from the Home Health Care Units of Haseki Training and Research Hospital were enrolled in the study. We retrospectively analyzed the patients' data from the hospital database, including their sociodemographic data. The study was approved by the Ethics Committee of Haseki Training and Research Hospital.

Statistical Package for the Social Sciences software version 11.0 was used for statistical analysis (SPPS Inc.; Chicago, IL, USA). The Chi-square test was used to assess differences of frequency between the two groups. The intergroup demographic data was compared using Student's t-test.

\section{RESULTS}

The distribution of the diseases according to etiology is shown in Table 1. It was shown that women were higher than man due to the general distribution of sex numbers that included the study. In addition to this, on analyzing the distribution of disease data; chronic kidney disease, ischemic heart disease, Parkinson's disease, epilepsy, and malignancy were most commonly seen (Table 1).

The mean blood analysis results for all patients are shown in Table 2. According to reference intervals in patient population, the CRP value in particular was found in high levels, whereas albumin value was observed at low levels (Table 2 ).

Mean blood analysis results by age 65 years are shown in Table 3. Compared with the patient group, urea, creatinine, and uric acid values were significantly increased in the group aged over 65 years. In addition, ALT, albumin, total iron binding capacity, $\mathrm{Hct}$, and hemoglobin were significantly decreased in the group aged over 65 years than in the younger group (Table 3 ).

Frequency distribution of disease according to ages is shown in Table 4. We also found that in group aged over 65 years, the frequency of hypertension and Alzheimer's was significantly increased. The frequency of cerebrovascular incidency, epilepsy, and malignancy were found significantly decreased (Table 4).

\section{DISCUSSION}

Home care health or supportive care is provided in the patient's home by healthcare professionals. A number of countries have invested in health services to provide care at home for patients to increase the proportion of the elderly population, which is those aged 65 years and over. The description of Home Care Services in Turkey was stated as the "Delivering of Home Care Services Regulation" published at the Official Government Gazette Number 25751, March $10^{\text {th }} 2005$ (13).

The demand for formal home care services has expanded due to many factors. These factors include migration of children from rural areas to urban areas, the increase in the number of women in employment, and social and economic deprivation (14). 
Table 2. Mean Blood Analysis Results for All Patients

\begin{tabular}{|c|c|}
\hline & Mean \pm SD \\
\hline Glucose (Glc) (mg/dL) & $112.07 \pm 50.17$ \\
\hline Urea (mg/dL) & $52.895 \pm 36.91$ \\
\hline Creatinine $(\mathrm{Cr})(\mathrm{mg} / \mathrm{dL})$ & $0.9269 \pm 0.7$ \\
\hline Uric acid (mg/dL) & $5.5574 \pm 2.36$ \\
\hline Aspartate aminotransferase (AST) (U/L) & $24.3052 \pm 23.68$ \\
\hline Alanine aminotransferase (ALT) (U/L) & $16.2615 \pm 13.86$ \\
\hline Gamma-Glutamyl Transpeptidase (GGT) (U/L) & $54.7022 \pm 93.63$ \\
\hline Lactate dehydrogenase (LDH) (U/L) & $277.3667 \pm 305.81$ \\
\hline Alkaline phosphatase (ALP)(U/L) & $105.5683 \pm 67.41$ \\
\hline Biliburin & $0.5738 \pm 0.336$ \\
\hline Albumin (g/dL) & $3.4291 \pm 0.48$ \\
\hline Total Protein (g/dL) & $6.6263 \pm 0.68$ \\
\hline C-reactive protein (CRP) (mg/L) & $11.5974 \pm 28.2$ \\
\hline Sodium $(\mathrm{Na})(\mathrm{mEq}(\mathrm{L})$ & $136.01 \pm 4.6$ \\
\hline Potassium $(\mathrm{K})(\mathrm{mmol} / \mathrm{l})$ & $4.48 \pm 0.56$ \\
\hline Calcium (Ca) & $9.07 \pm 0.66$ \\
\hline Cholesterol (mg/dL) & $183.85 \pm 44.11$ \\
\hline Triglyceride (Tg)(mg/dL) & $128.8 \pm 58.6$ \\
\hline $\mathrm{HDL}(\mathrm{mg} / \mathrm{dL})$ & $40.64 \pm 10.59$ \\
\hline $\mathrm{LDL}(\mathrm{mg} / \mathrm{dL})$ & $117.56 \pm 36.59$ \\
\hline Iron $(\mu \mathrm{g} / \mathrm{dL})$ & $51.47 \pm 26.66$ \\
\hline Total iron binding capacity ( $\mu \mathrm{g} / \mathrm{dL})$ & $262.16 \pm 76.52$ \\
\hline $\mathrm{HbA} 1 \mathrm{C}$ & $6.37 \pm 1.64$ \\
\hline Ferritin $(\mathrm{ng} / \mathrm{mL})$ & $126.67 \pm 179.23$ \\
\hline Folic acid (ng/mL) & $6.27 \pm 4.29$ \\
\hline B12 vitamin (pg/mL) & $455.02 \pm 380.41$ \\
\hline TSH (mIU/L) & $2.7 \pm 6.43$ \\
\hline FT3 (ng/dL) & $2.61 \pm 1.05$ \\
\hline FT4 (ng/dL) & $1.01 \pm 0.44$ \\
\hline НCT \% & $35.17 \pm 5.23$ \\
\hline $\mathrm{HGB}(\mathrm{g} / \mathrm{dL})$ & $11.44 \pm 1.79$ \\
\hline $\mathrm{MCH}(\mathrm{pg})$ & $28.46 \pm 3.099$ \\
\hline $\mathrm{MCHC}(\mathrm{g} / \mathrm{dL})$ & $32.53 \pm 1.23$ \\
\hline $\mathrm{MCV}(\mathrm{fL})$ & $87.39 \pm 8.13$ \\
\hline $\operatorname{PLT}\left(10^{3} \mu \mathrm{L}\right)$ & $262.57 \pm 102.88$ \\
\hline $\mathrm{RBC}\left(10^{6} \mu \mathrm{L}\right)$ & $4.04 \pm 0.6$ \\
\hline RDW \% & $15.66 \pm 2.47$ \\
\hline WBC $\left(10^{3} \mu \mathrm{L}\right)$ & $7.77 \pm 4.74$ \\
\hline
\end{tabular}

Scientific and technological advances in medicine have provided a rise in average life expectancy. In Turkey, according to Turkish Statistical Institute (TSI) reports, while the proportion of children and young in the total population decreases, the proportion of elderly in the total population increases.

If the current trends of demographic indicators persist, the population of Turkey will be among the countries that have a "too old" population. The proportion of population that was elderly was $8 \%$ in 2014, and it is expected that this will rise further to $10.2 \%$ in $2023,20.8 \%$ in 2050 , and will reach $27.7 \%$ in 2075 according to the population project. According to Elderly Statistics reports of the TSI, the three countries that had the greatest elderly population in 2012 were Italy with 21\%, Germany with $20.7 \%$, and Greece with $19.9 \%$, in United Nations Economic Commission for Europe (UNECE) countries. Turkey was $46^{\text {th }}$ on a list of UNECE countries in terms of elderly population proportions (15).

However, Turkey still has a young population compared with most other European countries, although the proportion of the population comprising older people is expected to increase in future years. This will necessitate a development in the perception of health care services. Current services are inadequate to meet the needs of the elder population. The government and other institutions in Turkey need to be ready to meet these increasing needs and enhance the quality of existing services in order to improve the living conditions of older people (16).

It must be also observed and analyzed how other developed countries have managed this situation. The United Kingdom is one of the countries that has made efforts to improve care of older people.

Previous studies include one published by Mergen et al. (11) who reported the legal and scientific point reached in home health care in Turkey; the authors observed that there were more than 3000 people for each family physician. They suggested that quality of home care service could be ameliorated with fewer patients per physician. In addition, results obtained by Akdemir et al. (17) showed the needs for home care organization and to form models of efficient home health services. Leff et al. (12) (2005) strongly proved that fewer complications occurred in patients who had hospital-at-home therapy than in patients who received hospital treatment. Furthermore, it was determined in Kim's research that patients with many medical complications and chronic diseases were likely to use home care (18).

One of the home care studies in 2011 showed that patients who received home care services had the two most common diseases, cerebrovascular disease and Alzheimer's. Presence of immobility-related complications such as depression, falls, and pain fluctuate, pressure sores and contractures for long phases after stroke were also documented by Sackley et al. (19).

This study aimed to statistically analyze the laboratory data of 575 patients who were followed up by the Home Health Care 
Table 3. Mean Blood Analysis Results by Age 65 years

\begin{tabular}{|c|c|c|c|}
\hline Blood Analysis & AGE & MEAN & $\mathbf{p}$ \\
\hline \multirow[t]{2}{*}{$\mathrm{GLU}(\mathrm{mg} / \mathrm{dL})$} & $<64$ & $109.04 \pm 54.81$ & 0.608 \\
\hline & $\geq 65$ & $112.47 \pm 49.56$ & \\
\hline \multirow[t]{2}{*}{ Urea (mg/dL) } & $<64$ & $34.39 \pm 22.46$ & $<0.001$ \\
\hline & $\geq 65$ & $55.43 \pm 37.78$ & \\
\hline \multirow[t]{2}{*}{$\mathrm{Cr}(\mathrm{mg} / \mathrm{dL})$} & $<64$ & $0.61 \pm 0.43$ & $<0.001$ \\
\hline & $\geq 65$ & $0.96 \pm 0.72$ & \\
\hline \multirow[t]{2}{*}{ Uric acid (mg/dL) } & $<64$ & $4.68 \pm 1.79$ & 0.004 \\
\hline & $\geq 65$ & $5.69 \pm 2.41$ & \\
\hline \multirow[t]{2}{*}{ AST (U/L) } & $<64$ & $26.98 \pm 19.81$ & 0.327 \\
\hline & $\geq 65$ & $23.94 \pm 24.15$ & \\
\hline \multirow[t]{2}{*}{ ALT (U/L) } & $<64$ & $23.13 \pm 15.68$ & $<0.001$ \\
\hline & $\geq 65$ & $15.33 \pm 13.34$ & \\
\hline \multirow[t]{2}{*}{ GGT (U/L) } & $<64$ & $87.46 \pm 117.39$ & 0.107 \\
\hline & $\geq 65$ & $46.88 \pm 85.83$ & \\
\hline \multirow{2}{*}{$\mathrm{LDH}(\mathrm{U} / \mathrm{L})$} & $<64$ & $438.52 \pm 652.26$ & 0.265 \\
\hline & $\geq 65$ & $242.33 \pm 139.93$ & \\
\hline \multirow[t]{2}{*}{$A L P(U / L)$} & $<64$ & $123.95 \pm 89.70$ & 0.205 \\
\hline & $\geq 65$ & $101.71 \pm 61.72$ & \\
\hline \multirow[t]{2}{*}{ Bilirubin } & $<64$ & $0.52 \pm 0.29$ & 0.340 \\
\hline & $\geq 65$ & $0.57 \pm 0.34$ & \\
\hline \multirow[t]{2}{*}{ ALB (g/dL) } & $<64$ & $3.74 \pm 0.49$ & $<0.001$ \\
\hline & $\geq 65$ & $3.39 \pm 0.46$ & \\
\hline \multirow[t]{2}{*}{ TPR (g/dL) } & $<64$ & $6.76 \pm 0.61$ & 0.119 \\
\hline & $\geq 65$ & $6.60 \pm 0.69$ & \\
\hline \multirow[t]{2}{*}{ CRP (mg/L) } & $<64$ & $21.73 \pm 48.63$ & 0.098 \\
\hline & $\geq 65$ & $10.04 \pm 23.31$ & \\
\hline \multirow[t]{2}{*}{$\mathrm{NA}(\mathrm{mEq}(\mathrm{L})$} & $<64$ & $137.77 \pm 3.80$ & 0.668 \\
\hline & $\geq 65$ & $138.04 \pm 4.69$ & \\
\hline \multirow[t]{2}{*}{$\mathrm{K}$ (mmol/L) } & $<64$ & $4.45 \pm 0.56$ & 0.611 \\
\hline & $\geq 65$ & $4.48 \pm 0.56$ & \\
\hline \multirow[t]{2}{*}{ CA } & $<64$ & $9.24 \pm 0.59$ & 0.058 \\
\hline & $\geq 65$ & $9.05 \pm 0.67$ & \\
\hline \multirow[t]{2}{*}{ Cholesterol (mg/dL) } & $<64$ & $187.62 \pm 42.86$ & 0.510 \\
\hline & $\geq 65$ & $183.38 \pm 44.29$ & \\
\hline \multirow[t]{2}{*}{$\operatorname{Tg}(\mathrm{mg} / \mathrm{dL})$} & $<64$ & $132.72 \pm 60.43$ & 0.598 \\
\hline & $\geq 65$ & $128.29 \pm 58.42$ & \\
\hline $\mathrm{HDL}(\mathrm{mg} / \mathrm{dL})$ & $<64$ & $41.13 \pm 12.14$ & 0.718 \\
\hline
\end{tabular}

\begin{tabular}{|c|c|c|c|}
\hline & $\geq 65$ & $40.58 \pm 10.40$ & \\
\hline \multirow[t]{2}{*}{$\mathrm{LDL}(\mathrm{mg} / \mathrm{dL})$} & $<64$ & $120.17 \pm 35.74$ & 0.582 \\
\hline & $\geq 65$ & $117.24 \pm 36.72$ & \\
\hline \multirow[t]{2}{*}{ Iron ( $\mu \mathrm{g} / \mathrm{dL})$} & $<64$ & $54.80 \pm 34.45$ & 0.452 \\
\hline & $\geq 65$ & $50.96 \pm 25.27$ & \\
\hline \multirow[t]{2}{*}{$\begin{array}{l}\text { Total iron binding } \\
\text { capacity }(\mu \mathrm{g} / \mathrm{dL})\end{array}$} & $<64$ & $301.44 \pm 78.79$ & $<0.001$ \\
\hline & $\geq 65$ & $256.06 \pm 74.45$ & \\
\hline \multirow[t]{2}{*}{$\mathrm{HbA1C}$} & $<64$ & $6.28 \pm 1.33$ & 0.119 \\
\hline & $\geq 65$ & $6.79 \pm 1.68$ & \\
\hline \multirow[t]{2}{*}{ FER (ng/mL) } & $<64$ & $125.39 \pm 257.33$ & 0.961 \\
\hline & $\geq 65$ & $126.85 \pm 165.99$ & \\
\hline \multirow[t]{2}{*}{$\mathrm{FOL}(\mathrm{ng} / \mathrm{mL})$} & $<64$ & $7.26 \pm 5.25$ & 0.390 \\
\hline & $\geq 65$ & $5.98 \pm 4.00$ & \\
\hline \multirow[t]{2}{*}{$\mathrm{B} 12(\mathrm{pg} / \mathrm{mL})$} & $<64$ & $441.93 \pm 332.57$ & 0.843 \\
\hline & $\geq 65$ & $456.96 \pm 387.72$ & \\
\hline \multirow[t]{2}{*}{ TSH (mIU/L) } & $<64$ & $6.45 \pm 14.91$ & 0.099 \\
\hline & $\geq 65$ & $2.10 \pm 3.31$ & \\
\hline \multirow[t]{2}{*}{ FT3 (ng/dL) } & $<64$ & $3.25 \pm 2.12$ & 0.093 \\
\hline & $\geq 65$ & $2.47 \pm 0.49$ & \\
\hline \multirow[t]{2}{*}{ FT4 (ng/dL) } & $<64$ & $1.03 \pm 0.88$ & 0.886 \\
\hline & $\geq 65$ & $1.01 \pm 0.31$ & \\
\hline \multirow[t]{2}{*}{ НCT \% } & $<64$ & $36.64 \pm 5.94$ & 0.014 \\
\hline & $\geq 65$ & $34.96 \pm 5.09$ & \\
\hline \multirow[t]{2}{*}{$\mathrm{HGB}(\mathrm{g} / \mathrm{dL})$} & $<64$ & $11.88 \pm 2.02$ & 0.033 \\
\hline & $\geq 65$ & $11.38 \pm 1.75$ & \\
\hline \multirow[t]{2}{*}{$\mathrm{MCH}(\mathrm{pg})$} & $<64$ & $27.60 \pm 3.59$ & 0.036 \\
\hline & $\geq 65$ & $28.58 \pm 3.00$ & \\
\hline \multirow[t]{2}{*}{$\mathrm{MCHC}(\mathrm{g} / \mathrm{dL})$} & $<64$ & $32.43 \pm 1.39$ & 0.493 \\
\hline & $\geq 65$ & $32.54 \pm 1.21$ & \\
\hline \multirow[t]{2}{*}{$\mathrm{MCV}(\mathrm{fL})$} & $<64$ & $84.99 \pm 9.34$ & 0.025 \\
\hline & $\geq 65$ & $87.74 \pm 7.88$ & \\
\hline \multirow[t]{2}{*}{$\operatorname{PLT}\left(10^{3} \mu \mathrm{L}\right)$} & $<64$ & $285.58 \pm 120.08$ & 0.050 \\
\hline & $\geq 65$ & $259.24 \pm 99.86$ & \\
\hline \multirow[t]{2}{*}{$\mathrm{RBC}\left(10^{6} \mu \mathrm{L}\right)$} & $<64$ & $4.33 \pm 0.69$ & $<0.001$ \\
\hline & $\geq 65$ & $4.00 \pm 0.58$ & \\
\hline \multirow[t]{2}{*}{ RDW\% } & $<64$ & $16.20 \pm 3.12$ & 0.129 \\
\hline & $\geq 65$ & $15.59 \pm 2.36$ & \\
\hline \multirow[t]{2}{*}{ WBC $\left(10^{3} \mu \mathrm{L}\right)$} & $<64$ & $8.08 \pm 2.96$ & 0.572 \\
\hline & $\geq 65$ & $7.73 \pm 4.95$ & \\
\hline
\end{tabular}


Table 4. Distribution of disease frequency by age 65

\begin{tabular}{|c|c|c|c|c|}
\hline ( \%)( No/Yes) & Age $<65$ years & Age $\geq 65$ years & $\mathbf{p}$ & Chi-square test $\left(x^{2}\right)$ \\
\hline Hypertension (HT) & $87.1 / 12.9$ & $67.1 / 32.9$ & 0.001 & 11.63 \\
\hline Diabetes Mellitus (DM) & $78.6 / 21.4$ & $68.3 / 31.7$ & 0.081 & 3.039 \\
\hline Heart Failure & $94.3 / 5.7$ & $94.5 / 5.5$ & 0.954 & 0.003 \\
\hline Ischemic Heart Disease & $98.6 / 1.4$ & $97.6 / 2.4$ & 0.617 & 0.250 \\
\hline Chronic Renal Failure & $100 / 0$ & $99.8 / 0.2$ & 0.709 & 0.139 \\
\hline Alzheimer's Disease & $98.6 / 1.4$ & $83.6 / 16.4$ & 0.001 & 11.099 \\
\hline Cerebrovascular accident & $54.3 / 45.7$ & $67.7 / 32.3$ & 0.026 & 4.954 \\
\hline Epilepsy & 92.9/7.1 & $97.8 / 2.2$ & 0.018 & 5.601 \\
\hline Parkinson's Disease & $100 / 0$ & $98.2 / 1.6$ & ns & \\
\hline Malignancy & $87.1 / 12.9$ & $96 / 4$ & 0.001 & 10.161 \\
\hline
\end{tabular}

Units of Haseki Training and Research Hospital between 2011 and 2013. Our study population mainly comprised elderly patients. The distribution of the diseases according to etiology and mean blood analysis results for all patients are shown in Tables 1 and 2.

We analyzed the laboratory results of 575 patients who were treated by the home care unit and underlined factors that may influence mortality. When factors with the potential to affect mortality of elderly patients were evaluated, the presence of low body mass index, low diastolic pressure, and low cholesterol have been defined in the literature (20).

Ponzetto et al. (21) examined factors that potentially had an impact on mortality in 987 inpatients aged over 70 years and reported that hypoalbuminemia, elevated creatinine, and fibrinogen values had a significant effect on mortality (21). Similarly, Silva et al. (22) included 856 patients aged over 60 years in their study and found hypoalbuminemia and increased creatinine levels were associated with mortality. In this study, the mean albumin level was $3.74 \pm 0.49$ in patients aged less than 65 years and $3.39 \pm 0.46$ in patients aged 65 years and over $(p<0.001)$ (Table 3).

The incidence of chronic renal failure (CRF) is more common among the elderly. Some chronic diseases that are frequently observed in elderly patients such as diabetes mellitus, hypertension, urinary obstructions, prostate hypertrophy or cancer-related hydronephrosis, and arterial obstructions resulting from atherosclerosis cause or increase the tendency for CRF. Long-term use of non-steroid anti-inflammatory drugs and some other analgesics may lead to CRF through chronic interstitial nephritis and papillary necrosis. It has been found in studies conducted on patients aged over 65 years that blood creatinine levels exceed the normal ranges in $17 \%$ of men and $14.4 \%$ of women (23). In our study, urea and creatinine levels were $52.89 \pm 36.91 \mathrm{mg} / \mathrm{dL}$ and $0.92 \pm 0.7 \mathrm{mg} / \mathrm{dL}$, respectively, for all patient groups. However, it was $55.43 \pm 37.78 \mathrm{mg} / \mathrm{dL}$ and $0.96 \pm 0.72 \mathrm{mg} / \mathrm{dL}$, respectively, for patients aged over 65 years and the results were significantly different as compared with those aged under 65 years $(p<0.001)$ (Table 3$)$.

The incidence of electrolyte imbalance in those aged over 55 years has been reported as 15\% (24). Accompanying diabetes mellitus, administered diuretics, and the amount of fluid intake are the most important factors that trigger such imbalance. In our study, we did not observe statistically significant data regarding electrolyte imbalance.

Fontana et al. (25) reported in their study that investigated 594 hospitalized elderly patients that reduced levels of T3, CRP, erythrocyte sedimentation, leukocyte, iron, albumin, and low total cholesterol were mortality markers. In the study carried out by Ayaz et al. (26) in Turkey, the laboratory findings of 1012 patients who were aged over 65 years of age and admitted to the internal medicine clinic for non-malignancy reasons were retrospectively analyzed; iron, total iron binding capacity, albumin, calcium, total cholesterol, and LDL and HDL levels were found significantly decreased in patients who died. On the other hand, erythrocyte sedimentation rate, urea, uric acid, creatinine, alanine aminotransferase (ALT), aspartate aminotransferase (AST), sodium, triglycerides, and CRP levels were significantly high in these patients. In the present study, the CRP level was found as $11.59 \pm 28.2 \mathrm{mg} / \mathrm{L}$, which is higher than the normal limits, in the total patient group. However, no statistically significant difference was detected when the patients aged more than 65 years were compared with those aged less than 65 years $(p=0.098)$.

Hyperlipidemia is a serious health problem, independent of age. Large epidemiologic studies have indicated that cardiovascular events significantly increase with age, both in men and women by age. In elderly patients, coronary heart disease is the major cause of morbidity and mortality. More than $80 \%$ of 
deaths resulting from coronary heart diseases occur in people aged over 65 years (27). The total cholesterol level was found over $240 \mathrm{mg} / \mathrm{dL}$ in $25 \%$ of men and $42 \%$ of women in the $\geq 65$ years age group (28). The total cholesterol, HDL, LDL, and triglyceride levels were found $183.85 \pm 44.11 \mathrm{mg} / \mathrm{dL}, 40.64 \pm 10.59$ $\mathrm{mg} / \mathrm{dL}, 117.56 \pm 36.59 \mathrm{mg} / \mathrm{dL}$, and $128.8 \pm 58.6 \mathrm{mg} / \mathrm{dL}$, respectively, and there was no significant difference between patients aged $\geq 65$ and $<65$ years (Table 3 ).

After the third decade, fasting plasma glucose rises 1-2 mg/dL per decade, and postprandial plasma glucose increases $15 \mathrm{mg} /$ $\mathrm{dL}$ per decade (29). The incidence of diabetes mellitus between 30 and 50 years of age ranges from $3 \%$ to $7 \%$, this rate is $20 \%$ in those aged between 65 and 70 years, and $40 \%$ in patients aged $\geq 80$ years (30). None of the currently available diabetes diagnosis guides separately define glycemic criteria in elderly people. Fasting plasma glucose is the best scanning test for elderly patients with diabetes (31). In our study, the fasting plasma glucose was measured as $109.04 \pm 54.81$ in patients aged under 65 years and $112.47 \pm 49.56$ in patients aged 65 years and over; however, this difference was not statistically significant $(p=0.608)$.

The free T3, free T4 TSH, and total T3 and T4 levels do not typically change in the normal aging process. Epidemiologic studies have indicated that the frequency of hypothyroidism elevates with age. A study performed in Colorado reported the prevalence of hypothyroidism as $21 \%$ in women and $16 \%$ in men aged $\geq 74$ years (32). Contrary to data in the literature, we obtained more elevated TSH values $(6.45 \pm 14.91 \mathrm{mIU} / \mathrm{L})$ in the under 65 years group, and no statistically significant difference was detected between the groups ( $\geq 65$ years; $2.10 \pm 3.31 \mathrm{mIU} / \mathrm{L}$ ) $(p=0.099)$.

Anemia is one of the major problems frequently observed in old age. The incidence of anemia rises with age and its presence is considered as an indicator of poor health (33). Hemoglobin level is affected by changes in the absorption of iron and vitamin B12, impaired erythrocyte production, blood loss, increased red blood cell destruction, or the combination of these conditions.

Changes related to hematocrit may reflect fluid intake and / or nutritional status in the elderly (34). Chernetsky et al. (35) found the anemia rate as $31.4 \%$ in the elderly in a geriatrics clinic in Israel and suggested that the most common cause of anemia was the anemia of chronic disease. Sahadevan et al. (36) retrospectively analyzed the data of 151 elderly patients who presented to the emergency service of the geriatrics department. The authors demonstrated that $1 / 3$ of the patients had anemia; the prevalence of anemia was $25 \%$ in the group aged $65-74$ years, and was $42.9 \%$ in the group aged 75 years and over. Smieja et al. (37) identified that $36 \%$ of 183 elderly patients who were admitted to their training clinic were anemic, in their retrospective analysis. Guralnik et al. (38) argued that in the U.S.S, $11 \%$ of women and $10.2 \%$ of men over the age of 65 years had anemia, and Choi et al. (39) reported the anemia prevalence to be $13.6 \%$ (14.7\% in women, $9.9 \%$ in men) in healthy Koreans aged over 60 years. Additionally, the prevalence of anemia in the elderly in Italy was reported by Inelman et al. (40) as $9.4 \%$ in men and $8.8 \%$ in women. The results of this study are consistent with the literature; the prevalence of anemia is statistically significantly high in the group aged 65 years and over. RBCs were also statistically significantly higher $\left(4.00 \pm 0.5810^{6} \mu \mathrm{L} ; \mathrm{p}<0.001\right)$.

The results of the present study comply with the literature in that patients aged 65 years or over being treated by the home care unit had high CRP but low albumin levels, and the prevalence of anemia was high among these patients. Although there were small differences according to normal ranges in other laboratory results, these differences were not significantly significant. These results show the favorable impact of home care on morbidity and mortality during follow-up and treatment of patients. We also found in the group aged over 65 years and over that the frequency of hypertension and Alzheimer's were significantly increased. The incidence of cerebrovascular disease, epilepsy, and malignancy were found significantly decreased (Table 4).

In conclusion, research considering home healthcare-specific issues carry great importance in Turkey by enlightening the health sector as to how it can improve the home care system. The number of studies is few and many questions remain. The lack of recent research in this field in Turkey underlines why more studies should be focused on this subject. The results obtained in this study supports the use of the home healthcare programs in more of the elderly population patients who spend time at home.

Ethics Committee Approval: Ethics committee approval was received for this study from the Ethics Committee of Haseki Training and Research Hospital.

\section{Informed Consent: N/A}

Peer-review: Externally peer-reviewed.

Author Contributions: Concept - Z.K., B.T., M.B.A., M.K., E.S.I., B.Ç.; Supervision - Z.K., B.T., M.B.A., M.K., E.S.I., B.Ç.; Materials - Z.K., B.T., M.B.A., M.K., E.S.I.; Data Collection and/or Processing - Z.K., B.T., M.B.A., M.K., E.S.I.; Analysis and/or Interpretation - Z.K., B.T., M.B.A., M.K., E.S.I., B.Ç.; Literature Search - Z.K., B.T., M.B.A., M.K., E.S.I.; Writing - Z.K., B.T., M.B.A., M.K., E.S.I.; Critical Reviews - Z.K., B.Ç.

Acknowledgment: The authors would like to thank to Mr. David Chapman for English editing.

Conflict of Interest: The authors have no conflict of interest to declare.

Financial Disclosure: The authors declared that this study has received no financial support.

Etik Komite Onayı: Bu çalışma için etik komite onayı Haseki Eğitim ve Araştırma Hastanesi Etik Kurulu'ndan alınmıştır. 
Hasta Onamı: Uygulanabilir değil.

\section{Hakem Değerlendirmesi: Dış bağımsız.}

Yazar Katkıları: Fikir - Z.K., B.T., M.B.A., M.K., E.S.I., B.Ç.; Denetleme Z.K., B.T., M.B.A., M.K., E.S.I., B.Ç.; Gereçler - Z.K., B.T., M.B.A., M.K., E.S.I.; Veri Toplanması ve/veya İşlemesi - Z.K., B.T., M.B.A., M.K., E.S.I.; Analiz ve/veya Yorum - Z.K., B.T., M.B.A., M.K., E.S.I., B.Ç.; Literatür Taraması Z.K., B.T., M.B.A., M.K., E.S.I..; Yazan - Z.K., B.T., M.B.A., M.K., E.S.I.; Eleştirel Inceleme - Z.K., B.Ç.

Teşekkür: Yazarlar İngilizce düzenlemelerinden dolayı David Chapman'a teşekkür etmektedir.

Çıkar Çatışması: Yazarlar çıkar çatışması bildirmemişlerdir.

Finansal Destek: Yazarlar bu çalışmanın finansal destek almadığını bildirmişlerdir.

\section{REFERENCES}

1. Tasdelen $\mathrm{P}$, Ates M. The Needs of Home Care Patients and the Burdens of their Caregivers. HEAD 2012; 9: 22-9.

2. Montauk SL. Home Health Care. Am Fam Physician 1998; 58: 1608-14.

3. Murkofsky RL, Alston K. The past, present, and future of skilled home health agency care. Clin Geriatr Med 2009; 25: 1-17. [CrossRef]

4. Jones AL, Harris-Kojetin L, Valverde R. Characteristics and use of home health care by men and women aged 65 and over. Natl Health Stat Report 2012; 52: 1-7.

5. Kisa S. Turkish nurses' concerns about home health care in Turkey. Aust J Adv Nurs 2008; 25: 97-106.

6. Turkish Prime Ministry. Socialization of Medical Services, No. 224, January 5, 1961. http://www.mevzuat.adalet.gov.tr/ html/1047. html. Accessed October 11, 2011.

7. Cho S. Older people's willingness to use home care nursing services. J Adv Nurs 2005; 51: 166-73. [CrossRef]

8. Hoye R, Sparatt J, Kolf J. Home health care: a physician's perspective. In: J. Sparatt, R. Hawley and R. Hoye (eds) Home health care: principles and practices. GR/St Lucie Pres Std: Florida, USA, 1997; 1-17.

9. Freeman S. Chambers K. Home health care: clinical pathways and quality integration. J Nurs Manag 1997; 28: 45-8.

10. Caffery C, Sengupta M, Moss A, Harris-Kojetin L, Valverde R. Home health care and discharged hospice care patients: United States, 2000 and 2007. Natl Health Stat Rep 2011; 1-27.

11. Mergen H, Unluoglu I, Elcioglu O. Contemporary Home Care Service and Family Medicine in Turkey. Home Health Care Manag Pract 2013; 25: 104-9. [CrossRef]

12. Leff $B$, Burton L, Mader SL, Naughton B, Burl J, Inouye SK, et al. Hospital at home: feasibility and outcomes of a program to provide hospital-level care at home for acutely ill older patients. Ann Intern Med 2005; 143: 798-808. [CrossRef]

14. Soylemez Z. Elderly Care and Elderly Structures in Turkey. Wuppertal: First Transnational Conference. 2006.

15. Turkish Statistical Institute-Elderly statistics 2014.

16. Saka $\mathrm{O}$, Varol N. Institutional and community care for older people in Turkey. Eurohealth 2007; 13: 20-2.

18. Kim EY, Cho E, June KJ. Factors influencing use of home care and nursing homes. J Adv Nurs 2006; 54: 511-7. [CrossRef]

19. Sackley C, Brittle N, Patel S, Ellins J, Scott M, Wright C, et al. The prevalance of joint contractures, pressure sores, paintful shoulder, other pain, falls and depression in the year after a severely disabling stroke. Stroke 2008; 39: 3329-34. [CrossRef]
20. Vischer UM, Safar ME, Safar H, laria P, Dudal KL, Henry O, et al. Cardiometabolic determinants of mortality in a geriatric population: is there a "reverse metabolic syndrome"? Diabetes Metab 2009; 35: 108-14. [CrossRef]

21. Ponzetto M, Maero B, Maina P, Rosato R, Ciccone G, Merletti F, et al. Risk factors for early and late mortality in hospitalized older patients: the continuing importance of functional status. J Gerontol A Biol Sci Med Sci 2003; 58: 1049-54. [CrossRef]

22. Silva A, Jerussalmy CS, Farfel JM, Curiati JAE, Jacob-Filho JAE. Predictors of in-hospital mortality among older patients. Clinics. 2009; 64: 613-8. [CrossRef]

23. Garg AX, Papaiannou A, Ferko N, Campbell G, Clarke J, Ray JG. Estimating the prevalence of renal insufficiency in seniors requiring long term care. Kidney Int 2004; 65: 649-53. [CrossRef]

24. Funk GC, Lindner G, Druml P, Metnitz B, Schwarz C, Bauer P, et al. Incidence and prognosis of dysnatremias present on ICU admission. Intensive Care Med 2010; 36: 304-11. [CrossRef]

25. Fontana L, Addante F, Copetti M, Paroni G, Fontana A, Sancarlo D, et al. Identification of a metabolic signature for multidimensional impairment and mortality risk in hospitalized older patients. Aging Cell 2013; 12: 459-66. [CrossRef]

26. Ayaz T, Sahin SB, Sahin OZ, Bilir O, Rakıcı H. Factors Affecting Mortality in Elderly Patients Hospitalized for Nonmalignant Reasons. J Aging Res 2014; 2014: 584315. [CrossRef]

27. Grundy SM, Cleeman Jl, Rifkind BM, Kuller LH. Cholesterol lowering in the elderly population. Coordinating Committee of the National Cholesterol Education Program. Arch Intern Med 1999; 159: 1670-8. [CrossRef]

28. National Lipid Education Council. Treating dyslipidemia in the elderly: Are we doing enough? Lipid Management Newsletter 1999; 4: 1.

29. Samos LF, Roos BA. Diabetes Mellitus in older persons. Med Celin N Am 1998; 82: 791-803. [CrossRef]

30. Harris MJ. Epidemiology of diabetes mellitus among elderly in the US. Clin Geriat Med 1990; 6: 703-19. [CrossRef]

31. Morrow LA, Halter JB. Treatment of the elderly with diabetes. In; KAHN CR, Weir GC. Eds. Joslin's diabetes mellitus. Waverly Int 1996; 552-9.

32. Parker CR, Blackwell PJ, Pairburn KJ, Roskin DJ. Alenduronate in the treatment of primary hyperparathyroid-related osteoporozis: a 2-year study. J Clin Endocrinol Metab 2002; 87: 4482-9. [CrossRef]

33. Smith DL. Anemia in the elderly. Am Fam Physician 2000; 62: 1565-72.

34. Fischbach FT. A manual of laboratory and diagnostic tests (7th ed). Philadelphia: Lippincott. 2004.

35. Chernetsky A, Sofer O, Rafael C, Ben-Israel J. Prevalence and etiology of anemia in an institutionalized geriatric population. Harefuah 2002; 141: 591-4.

36. Sahadevan S, Choo PW, Jayaratnam FJ. Anemia in the hospitalized elderly. Singapore Med J 1995; 36: 375-8.

37. Smieja MJ, Cook DJ, Hunt DL, Ali MA, Guyatt GH. Recognizing and investigating iron-deficiency anemia in hospitalized elderly people. CMAJ 1996; 155: 691-6.

38. Guralnik JM, Eisenstaedt RS, Ferrucci I, Klein HG, Woodman RC, et al. Prevalence of anemia in persons 65 years and older in United States: evidence for a high rate of unexplained anemia. Blood 2004; 104: 2263-8. [CrossRef]

39. Choi CW, Lee J, Park KH, Yoon SY, Choi IK, Oh SC, et al. Prevalence and characteristics of anemia in the elderly. Cross-Sectional Study of Three Urban Korean Population Samples. Am J Hematol 2004; 77: 26-30. [CrossRef]

40. Inelmen EM, D'Alessio M, Gatto MR, Baggio MB, Jimenez G, Bizzotto $M G$, et al. Descriptive analysis of the prevalence of anemia in a randomly selected sample of elderly people living at home: some results of an Italian multicentric study. Aging 1994; 6: 81-9. 